\title{
POSITIVE IMPACTS OF LOVE \\ IN WILLIAM A. WELLMAN'S AND ROBERT CARSON'S MOVIE SCRIPT A STAR IS BORN
}

\author{
Cindy Yana Mentari, Devi Pratiwy \\ Faculty of Literature, Universitas Islam Sumatera Utara, \\ Medan, Indonesia \\ e-mail: cindyyanamentari@gmail.com
}

Received: 2021-09-06

Accepted: 2021-11-12

\begin{abstract}
This study aims to determine the positive impacts of love in the movie script A Star Is Born. This study is concerned with the types of love which imply the positive impacts. This study uses Fromm's theory of love. The types of love analyzed in this study are brotherly love, erotic love, and self-love. Next, the positive impacts of love found in this study are for health, for personal ties, and for relationship. This study uses descriptive qualitative method to explain the types of love that imply positive impact, and positive impact of love from the quotations in the script. This film tells the story of an ordinary woman with great talent who accidentally meets a male celebrity who is addicted to alcohol. The man is attracted to the woman who has a dream to conquer Hollywood. He pushes her become a star. The results of this study show that love can have a positive impact for health that triggers Jack to be released from drugs and alcohol. Besides, the self-love in this movie is presented when Jack helps Ally to be more confident and love herself; consequently, she can be a successful songwriter and singer. Jack always loves her as she is. Ally always supports his health. Both of them strengthen and heal each other.
\end{abstract}

Keywords: Love, Types of Love, Positive Impact of Love, brotherly love, erotic love

\section{Introduction}

In the course of human life, love will never be separated. Love will always exist in a dimension of human being. Love is a natural feeling that is felt by a person towards other people, especially towards the opposite sex. Feelings of mutual love, belonging, fulfilment, and mutual understanding that cannot be forced at all. Therefore, two people who love each other will make a relationship commitment to bind these feelings of love so that it becomes something that can bring happiness and peace to their lives.

A Star is Born is an American romantic musical drama film starring Lady Gaga and Bradley Cooper. Not only as a film star, Bradley Cooper also directed this film. This scene of the film was written by William A. Wellman and Robert Carson. The film was premiered at the 75th Venice International film festival on 31 August 2018 and was released in the United States on 5 October 2018 by Warner Bros. The story of the film $A$ Star is Born is the fourth remake of the old film of the same name which was released in 1937. 
Positive Impacts of Love in William A. Wellman's and Robert Carson's Movie Script A Star Is Born, Cindy Yana Mentari, Devi Pratiwy

In Bradley's version committed, A Star is Born received positive reviews from fans and film. In this film, Jackson Maine (Bradley Cooper) is a country musician whose career is fading. Jackson was addicted to alcohol and drugs. When he finishes performing in California, Jackson stopped by a bar. At the bar there was a live music performance and Jackson accidentally heard the sweet voice of a female singer. This female singer is Ally (Lady Gaga), a bar waitress whose voice has managed to rivet Jackson. Jackson and Ally then became acquainted; Jackson was increasingly amazed at Ally because it turned out that he was also tenanted in writing song lyrics.

Then, Jackson invites Ally to appear on a stage his music tour; they fall in love and date. Ally's appearance on one of the Jackson tours caught the attention of record producer, Rez (Rafi Gafron). Rez then offered Ally a record contract as a pop singer. Even though Jackson objected, he still supported Ally in pursuing her dream as a professional singer. However, Ally's busy work on the new album slowly took her away from Jackson, and they had disagreements. Jackson decides to come to Ally's house, they make up and Jackson proposes to Ally.

Based on the story of the movie script, it shows dominantly the positive impacts of love played by the characters, Ally and Jack. The story, which at first moves slowly and carefully, then rolls freely. "I like writing songs, but it's better not to sing them. Because, people like my voice but not my big nose, "Ally confided in Jack. However, Ally and Jack rejected it. For them, music is an escape that can only be perfect if you can sing well and loose, without the shadow of the industrial hand. Music is a time when you can be yourself. That's what Jack was trying to live with. However, Ally, who was initially reluctant to serve the industry, was forced to give up. After being frequently asked to contribute songs at music concerts with Jack, Ally is looked at by star-scorer manager Rez Gavron (Refi Gavron). This dominant thing is what I make the problem in my research which is summarized in the statement of the problem below.

There are three reasons to analyze this script. The first reason is no one has done research on this script before; the second is knowing and understanding the positive impacts of love that exist in the script; and the last, this script is interesting from the beginning to end.

\section{Literature Review}

In general, love is an emotion or positive feeling (kindness, compassion, affection) within humans which is directed at other humans or other objects around them. Stenberg (1988: 48), states that love is the deepest and most desirable form of human emotion. Humans may lie, cheat, steal and even kill in the name of love and it is better to die than lose love. Love can pervade everyone and of all ages. Meanwhile, according to Hendrick and Hendrick (1992: 533), there is no single phenomenon that can describe how love is; in the end, love is a complex set of emotion al and mental states. Basically, the types of love experienced by each individual have different forms and different qualities.

Love is an attitude directed by a person towards other people who are considered special, which affects the way they think, feel and behave.

According to Libowitz (in Wortman, 1992: 65), love is a strong positive feeling that we feel towards someone and is the strongest positive feeling we have ever experienced. In any type of love, the element of caring for the loved one is very important. Without an element of pure caring, what is called love may be just desire. Apart from the element of attention, the element of respect is also needed. Respects that 
will make individuals respect the identity and integrity of loved ones so as to avoid problems of exploitation. From the definitions mentioned, it can be concluded that love is a complex set of emotional and mental states affect the way a person thinks, feels and behaves.

Love is one of the famous things in the world. Love is a feeling interest to others which guide a person to make a decision in a relationship. Based on theory of love from Erich Fromm (2005: 10), Love is a dynamic interaction lived in each of our lives. So, love is everywhere. Love is an active activity. Therefore, love has the freedom to determine itself and to love is to give freedom for the growth of a loved one. Thus love is not a passive influence. The most obvious activity in the activity of love and love is giving. (Fromm, 2005: 11). According to Fromm, so far there have been extraordinary mistakes in the act of "giving". Giving is often equated with "giving" something or sacrificing something. Giving here according to Fromm is not just giving material, but self, the presence, beyond that the existence, the spirit of life and the feeling of being together. Strictly speaking, the act of giving lies not in material matters, but in human realism itself.

Based on several definition of love mentioned above, this study uses the concept of love given by Fromm (2005). He explains that love is active. It means love can brings about something including its impact. Such love is portrayed in the movie A Star Is Born.

\subsection{Types of Love}

Love is an attitude oriented character and personal relationship with the world as a whole, without being limited by the object of love (Fromm, 2005: 6). However, Fromm added that love has different types depending on the object it loves. Then, Fromm classified love into five types namely:

\section{a. Brotherly Love}

This love is for all human beings based on the experience that we are one. Differences in skin color, talent, intelligence or knowledge can be ignored when we think about the core identity of humanity. This type of love is the most fundamental of all types of love. Loving blood is not an achievement, because animals also love their blood and flesh; take care of her children. The poor love the rich because their life depends on them. Only love that has no "interest" will become true love. He gave an example such as loving poor people, foreigners, orphans, enemies and others. (Fromm, 2005: 47).

\section{b. Motherly Love}

Motherly love for a growing child, love that wants nothing for her, this is perhaps the hardest to achieve. But it was precisely because of this difficulty that his love lasted. Maternal love according to Fromm is considered the highest type and the most sublime emotional attachment. Uniquely for Fromm, if another love wants union, but in this kind of motherly love, a mother loves her child to separate from her dependence at a later dates. (Fromm, 2005: 49).

\section{c. Erotic Love}

Erotic love is love that craves fusion and union with another. Fromm does admit that sexual relations are the actualization of love in this type of erotic love, but 
Positive Impacts of Love in William A. Wellman's and Robert Carson's Movie Script A Star Is Born, Cindy Yana Mentari, Devi Pratiwy

love that is emphasized is productive love which contains elements of care, responsibility, respect and understanding. (Fromm, 2005: 52).

\section{d. Self-love}

Self-love is egocentric. Self-love as long as it doesn't interfere with other love is a positive actualization. However, when he enters the area of egoism which tends to behave in a self-beneficial manner, or narcissism, this love will turn negative.

Loving one means actualizing and concentrating his strength on loving others. If this is the case, he becomes a productive person. (Fromm, 2005: 57).

\section{e. Love for God}

In all theistic religions, whether polities or monotheists, God is the ultimate, most coveted reality. The specific meaning of God depends on what a person longs for most. This kind of love is the same as love for parents. Love to Allah begins with a helpless attachment to Him who is maternal (matrilineal), then attachment and obedience to Him who is fatherly (patrilineal), until one day the person incorporates the principles of truth and justice in himself, so that he becomes one with Him, and finally got to the point where it transferred the divine qualities to him. (Fromm, 2005: 63)

\subsection{Elements of Love}

Fromm identified four elements which are common to all forms of love. The four elements are:

\section{a. Care (attention)}

Care is one of the attitudes that humans must have when they love other people. Indispensable in a behavior called love in order can understand life, progression back and forth, good or bad, and how is the well-being of the beloved object.

\section{b. Responsibility}

Responsibility required in having a relationship. Because without responsibility there will be no equal distribution. The responsibility here is not for dictate beloved object at will we, but how involvement in the life of a beloved object.

\section{c. Respect}

Respect here means the ability to see someone as they are, by realizing all the uniqueness that exists in that person. Respect means caring for others so that they grow and develop according to themselves. The beloved figure is allowed to grow and develop in its own way and for its own sake, not being forced to develop for the passion and ambition of the person who loves it. If we love, we feel at one with the person as they are.

\section{d. Knowledge}

The knowledge here is a deep understanding that can penetrate the core of the problem. This kind of knowledge is only possible if we can go beyond paying attention to ourselves and then see others in their own context. In love, we can only know through understanding what is alive in humans - by experiencing oneness, not through the knowledge imparted by the mind. 


\subsection{Positive Impact of Love}

According to Kamus Besar Bahasa Indonesia (1997), impact means collision; strong influence that have consequences (both negative and positive). The writer concludes that impact is everything that arises the result of an event or development in society and produce changes that have a positive or negative effect against survival. Positive impact means showing change for the better, while the negative impact means indicates a change for the worse.

Falling in love definitely has an impact on a person, such as a positive or negative impact. Because the theory discussed by Fromm does not deal with the positive impact of love, then another theory was taken to support the analysis. The theory taken is proposed by Alan Behrens.

According to Behrens (2018), love makes the world go around; love for one another, love that we profess towards our family and friends, or even love for ourselves. When it comes to defining this love, we often find it hard to do in simple terms. But it is a powerful motivator one that can affect us both physically and emotionally. It underscores all the relationships that we form in the course of our natural lives but it comes with its own baggage. This is why we need to take a closer look at some of the positive impact of love.

a. Love for health is that various studies have indicated that loving someone of having someone to love can help contribute to good health. Each time we express our love to that person, our brain release serotonin which is a feel-good hormone. So, with more love to go around, our health is bound to improve over the long run.

b. Love for personal ties is that love can help us form close personal bonds with others. As a species, we are quite sociable and often form various relationships in the course of a single life time. And that's why love or feelings of deep mutual affection that we share with others can help us cement that relationship and even help make it permanent.

c. Love for relationship is that love can help cement relationships and this is one of the reasons why most married couples are advised to renew their vows after a certain period to affirm their love for each other.

\section{Research Method}

Qualitative method with narrative approach was conducted in this study. Narrative research is a strategy of inquiry in which the researcher studies the lives of individuals and asks one or more individuals to provide stories about their lives. This information is then often retold or restored by the researcher into a narrative chronology. In the end, the narrative combines views from the participant's life with those of the researcher's life in a collaborative narrative (Clandinin \& Connelly, 2000). Data collection in this study is documentary study techniques. This technique is used to describe data in the form of documents for research studies. The study is conducted by classifying the obtained data in two sub-chapters related to the research problem.

\section{Discussion}

Types of love are presented in the movie script. They imply positive impact. All are described in the following. 
Positive Impacts of Love in William A. Wellman's and Robert Carson's Movie Script A Star Is Born, Cindy Yana Mentari, Devi Pratiwy

\subsection{Types of Love in the Movie Script}

The types of love which imply positive impact that emerge from this research are brotherly love, erotic love, and self-love. These three types are based on the theory presented before.

\section{Brotherly Love}

Brotherly love means love for all human beings. If our love has developed the ability to love, it means inevitably we must love our brothers. In brotherly love, there is experience of unity with our fellow human beings, experience of peace, and solidarity between people. In the script A Star Is Born, Bobby is Jack's older brother and his manager who loves him. It can be seen in the following quotation:

\section{BOBBY}

(interrupting)

The doctor said it's the only way to manage this thing, Jack. You're not gonna get back what you lost. It's the only way we can manage what you still got. (Wellman and Carson, 2018: 46)

The quotation describes that Bobby, Jack's older brother and manager come to outdoor amphitheater stage. He approaches Jack who is practicing singing. He walks over to him and holding up a device for his ear. He says that Jack had to put his hearing aid in his ear but he refuses because he wants to perform without it. Bobby cares about his situation and states that this is a way to keep what he still had.

\section{BOBBY}

What did you think, that I was gonna fucking take care of it while I'm fucking cradling your ass all over the goddamn world?

(Wellman and Carson, 2018: 71)

It shows that they get into a fight when Jack knows that Bobby sold their father's land. Jack hits Bobby until he fell. Then, he tries to get up and explains that it is actually already told by him but Jack is not aware because at that time he was very drunk. Bobby grabs Jack's face, pulling him close, nose-to-nose and feels sad because his brother dared to hit him even though he had raised him from a young age become famous as he is now.

\section{BOBBY}

(re: Jack's hearing) Is it getting worse?

\section{JACK}

Nah, I've just been with my wife... It's going real good. (beat)

Funny to run into you 'cause, uh, I was thinking about asking you to come back out with us.

\section{BOBBY}

I gotta say, it's easier without you.

\section{BOBBY}

Listen. You run into any trouble... call me.

(Wellman and Carson, 2018: 114-116)

The quotation explains that Bobby's sincere love for his brother makes them reconcile when Bobby decides to stop being Jack's manager. After that fight, they never meet again. But accidentally, at the backstage, they meet again. They are there because 
Jack accompanies his wife, Ally, on a gig while Bobby has been working for Willie. They greeted each other even Jack has asked Bobby to return being his manager again but he does not want to. He says that if Jack had a problem, he can call him.

\section{Erotic Love}

Erotic love is a love that craves a total smelting and personal union with another. In essence, it is exclusive and not universal. In the script A Star Is Born, erotic love occurs when Jackson proposes to Ally with a ring that he made with guitar strings. It can be seen in the following quotation:

\section{ALLY}

(laughing)

Are you kidding?

\section{JACK}

(quietly)

Well, that's a stupid thing I just did.

ALLY

(quietly)

No. It's not stupid.

(Wellman and Carson, 2018: 101)

The quotation clarifies that when at Noodles' house, Jack's friend, he makes a ring out of guitar strings. He gives it to Ally as a sign that he is serious about a relationship with her. Ally is in disbelief and asks if this is a joke. The two who meet through music made them know each other and built a relationship so that they will unite their love with marriage bond.

\section{Self-Love}

Self-love is a state of appreciation for oneself that grows from actions that support our physical, psychological and spiritual growth. Self-love means taking care of your own needs and not sacrificing your well-being to please others. In the script A Star Is Born, self-love occurs when Jack helps Ally to love herself. It can be seen in the following quotation:

\section{JACK}

Hey, I got a gig. You wanna come?

ALLY

When?

PHIL

We're headed to the airport now. (Wellman and Carson, 2018: 39)

It shows that after telling many things and getting to know each other in that night, Jack drives Ally home at that moment. When they get to her house, Ally should probably get out of the car but they do not want to leave each other. Having seen a talent for singing and songwriting, he asks her to come with him to the concert that he was attending.

(into mic)

\section{JACK}


Positive Impacts of Love in William A. Wellman's and Robert Carson's Movie Script A Star Is Born, Cindy Yana Mentari, Devi Pratiwy

Thank you very much. That was great... There's a friend of mine, who came a long way to be here... She wrote a great song, and I'd just like her to sing it. I think it's pretty fucking good.

(Wellman and Carson, 2018: 55)

The quotation describes that unexpectedly, Ally and his friend, Ramon leave work and they go to attend Jack's concert. They go by private jet. When they arrive at the outdoor amphitheater, they are greeted by Gail, a coordinator. She asks them to follow her towards the stage. They are beside the stage to watch Jack. After finishing, he introduces her to the audience and asks her to sing a song that she has composed with him at a concert. As it turned out, Ally's songs are liked by concertgoers.

\section{JACK}

All right, listen to me. Here's what we're going to do. You're going to do the song that I said that I wanted you to do, remember? The one that I love. (Wellman and Carson, 2018: 77-78)

The quotation above explains that after performing a concert with Ally yesterday, Jack invites her again to come with him to Arizona to attend a music festival concert. They sing a duet there. After singing, Jack gets the idea that he will ask Ally to sing a solo by singing a song that she composes while at the Arizona restaurant. At first, she refuses but Jack assures her that she has to do this. She agrees and then he invites her to bring the original song. Unexpectedly, it is successfully glimpsed by music producer.

\subsection{Positive Impacts of Love}

Impact is a collision, an influence that has both positive and negative consequences. The impact contained in this study is a positive impact. Positive impact is the desire to persuade, convince, influence, or impress others with the aim that they follow or support the good wishes. The positive impact in this research such as for health, for personal ties, and for relationship.

\section{For Health}

Falling in love can make a person feel always happy and cheerful in life. So that, if two people who love each other will always provide positive energy in it. In the script A Star Is Born, Ally's presence can provide positive energy for Jackson's health.

\section{ALLY}

I don't know, I guess I wondered without the booze, you know, if you would want to come home. 'Cause when you met me you were drinking and now you're not. (Wellman and Carson, 2018: 144-145)

The quotation describes that Ally and Jack meet at rehab facility. They meet there because Jack is in a drug rehab program. They ask each other how they are and their activities. Ally says that she misses him and waits for him to come back home. She asks if he will be back home when he has done and she feels sad because of thinking of what if he is without booze but he has to do this because he needs to stick with her. 


\section{For Personal Ties}

As social beings, bonding with other humans is vital to our mental and emotional well-being. Especially if they love, support, give a motivation and there are for each other. When we feel positive from within, we will radiate positivity, which in turn will make us more creative and productive in life. In the script A Star Is Born, Jack always gave a motivation for Ally that she can become a famous singer.

\section{JACK}

You know, I had a thing when I was little. I was born with this thing in my ear. Couldn't hear... What do I wind up being? A singer. So you never know... (then)

Look... Talent comes everywhere, everybody's talented. I bet you, fucking everybody in this bar is talented in one thing or another, but having something to say, and a way to say it so people listen to it, that's a whole other bag. And unless you get out there and you try to do it you'll never know. That's just the truth. If there's one reason we're supposed to be here, it's to say something so people want to hear it. (Wellman and Carson, 2018: 26)

The quotation above points out that Jack tells Ally about his life that he has tinnitus and was born with a thing in his ear could become a famous rock singer. He says that no one knows what a person's fate will be like because everyone has talent. He also motivates her that to be a successful person is not always seen from the physical but also from the talent she has.

ALLY

(apologetic)

I've never sang with a track before.

\section{JACK}

Listen, you know what I think it is -- I think it's because you need your

piano. I think if you're playing it and singing it... and then with the rhythm... (Wellman and Carson, 2018: 84-85)

The quotation above clarifies that Jack is accompanying Ally recording in the studio. Since she is used to sing on the piano, she feels awkward when she only sing to the rhythm of the music. The rhythm does not fit so the producer asks her to repeat. Jack immediately advises her to sing by playing the piano because it will make it easier for her.

\section{JACK}

You've been nominated for three Grammys and it's fucking great.

\section{ALLY}

Thank you. How did you find that out?

(Wellman and Carson, 2018: 119)

The quotation distinctly describes that in the morning, Ally comes home after recording. She meets with Jack and asks how her husband is. After that, Jack plays with his dog. Then, he goes into the room and sees Ally is in the bathroom. He meets her and sits down on the bath's edge. He congratulates Ally on her three Grammys nominations. $\mathrm{He}$ is proud that she has managed to become a famous pop singer. 
Positive Impacts of Love in William A. Wellman's and Robert Carson's Movie Script A Star Is Born, Cindy Yana Mentari, Devi Pratiwy

$$
\text { (into mic) ALLY }
$$

Oh, wow! Oh, my gosh! I can't believe I'm holding one of these. Thank you to Rez Gavron, my manager. Thank you for believing in me and telling me to get back from behind the piano and onto the stage.

Yeah, I do.

$$
\text { ALLY }
$$$$
\text { (placating) }
$$

(then; over speakers) I started out singing with this beautiful man and I'll sing with him for life. (pulling Jack back together) Right, baby?

(Wellman and Carson, 2018: 136-137)

It shows that Ally feels grateful that she manages to get the award. This victory feels like a dream to her. She is grateful to Rez Gavron, her manager who has trusted her in singing and she is also grateful to Jack Maine, her husband who always provides motivation, support, and enthusiasm to realize her dream of becoming a great singer. She also says that she started singing with a man who always supports her from the beginning until now.

\section{For Relationship}

In a relationship, it is normal to have each other's opinion. Likewise with partners, we will surely find every flaw in the relationship process because no human being is perfect. However, this deficiency factor is the key so that couples can understand and complement each other. In the movie script A Star Is Born, for relationship occurs when Ally hates herself. The following quotation proves for relationship:

\section{ALLY}

Um... Well, 'cause, like, almost every single person that I've come in contact with in the music industry has told me that my nose is too big and that I won't make it.

\section{JACK}

Your nose is too big?

\section{ALLY}

Yeah.

\section{JACK}

Your nose is beautiful.

(Wellman and Carson, 2018: 23)

The quotation explains that Ally tries to contact the music industry but she is rejected. So, she begins to lose her enthusiasm for pursuing her dream. She hates herself because of her physique that does not sell. In fact, Jack does not judge Ally's beauty from physical alone. He loves her just the way she is.

\section{JACK}

$$
\text { (crying) }
$$

I'm sorry I did that. 
ALLY

It's okay. It's not your fault. It's a disease.

JACK

(crying)

No, but I embarrassed you. I embarrassed you.

$$
\text { ALLY }
$$

I'm not embarrassed of you.

(Wellman and Carson, 2018:147)

In the above-mentioned quotation, it illustrates that while in rehab, Jack apologizes to Ally for what happen during the Grammys nominated awards night. He feels that he has embarrassed her because at that moment he is very drunk and passed out. She already knows that he was an addict, but she does not leave him, she even supports him to get well.

\section{Conclusion}

Having conducted the analysis on the positive impacts of love, it can be concluded that there are three types of love found in the movie. The three types of love imply positive impacts. The positive impacts of the love in the move involve for health, for personal ties, and for relationship. Jack gets support and loves from his next brother. Jack and Ally love music and never stop fighting for their dreams. The two who meet through music make her a star so that they are united by marriage bond. Love for health occurs when Jack's way of loving himself is wrong at first, but he begins to open up when he met Ally. He sees hope and awareness of wanting to be free from the entanglement of drugs and alcohol. Self-love occurs when Jack helps Ally to love herself so that she can love herself and develop into a successful songwriter and singer. Love for relationship occurs when Ally hates herself because of her physique that does not sell, Jack does not actually judge Ally's beauty from her physical appearance alone. He loves her just the way she is. Likewise with Ally, after finding out that Jack is an addict, she does not leave him, she even supports him to get well. The two of them together strengthen and heal each other. Love for personal ties occurs when Jack says that she can make her dream come true so he motivates and supports her.

\section{References}

Behrens, A. (2018). Positive Negative Impact. Retrieved from https://positivenegativeimpact.com/love

Clandinin, D. J. and Connelly, F.M. (2000). Narrative Inquiry: Experience and story in qualitative research. San Francisco: Jossey-Bass,

Departmen Pendidikan dan Kebudayaan. (1997). Kamus besar bahasa Indonesia, Jakarta: Balai Pustaka.

Fromm, Erich. (2005). The Art of Loving. Jakarta: Gramedia Pustaka Utama.

Hendrick, S. S, \& Hendrick, C. (1992). Liking, loving, and relation (2nd ed). California: Brooks/Cole Publishing Company Pacific Grove.

Stenberg, R.J. (1988). The Triangle of Love. New York: Basic Books Inc.

Wellman, W. A. and Carson, R. (2018). A Star Is Born. New York: Warner Bros

Wortman, Camille \& Loftus, Elizabeth. (1999). Psychology. New York: McGraw.Hill Companies. 